\title{
Changes in Religious Giving Reflect Changes in Involvement: Age and Cohort Effects in Religious Giving, Secular Giving, and Attendance
}

\author{
MARK O.WILHELM \\ PATRICK M. ROONEY \\ EUGENE R. TEMPEL
}

\begin{abstract}
We present two patterns over time in religious giving, secular giving, and religious service attendance. The first pattern describes the prewar cohort (born 1924-1938) as they aged between middle adulthood (ages 35-49) and their senior years (ages 62-76). The second pattern compares the baby boom cohort (born 1951-1965) in middle adulthood to the middle adulthood of the prewar cohort. We present patterns for all families as well as separately for Catholic and Protestant families using data from three sources. The prewar cohort increased their religious giving and attendance as they aged, but—compared to the prewar cohort in middle adulthood—baby boomers give less than expected to religion and attend less. Baby boomer giving is noticeably less-than-expected and attendance noticeably lower among Catholic boomers, but less so among Protestant boomers. We argue that together these patterns are evidence that changes in religious giving reflect changes in religious involvement.
\end{abstract}

\section{INTRODUCTION}

We present evidence that recent changes in American religious giving reflect changes in religious involvement. Chaves and Miller's (1999) edited collection describes recent changes in religious giving, and Chaves (1999) argues that the giving changes reflect involvement changes. Starting with the observation that religious giving is lower than would have been expected from earlier trends, Chaves' argument is that lower-than-expected religious giving reflects an underlying decline in religious involvement because at any point in time religious giving is correlated with religious involvement.

The argument is a priori compelling, but not the only possible explanation of changes in religious giving. It is also possible that the religious giving of the religiously involved is lowerthan-expected because they have diverted some of their giving to other purposes, such as human services, poverty relief, education, health, and international aid. Diversion could occur if the religiously involved consider other-purpose giving to be a close substitute for giving to their local congregation or its national affiliate.

In addition, the argument that across-time changes in religious giving reflect across-time changes in involvement is not based on across-time evidence. Rather, the argument hinges on pointin-time evidence that religious giving and religious involvement are complementary activities (in

\footnotetext{
Correspondence should be addressed to Mark O. Wilhelm, Department of Economics, Indiana University-Purdue University at Indianapolis, 425 University Boulevard, Indianapolis, IN 46202.E-mail:mowilhel@iupui.edu

Mark O. Wilhelm is Associate Professor of Economics and Philanthropic Studies at Indiana University-Purdue University at Indianapolis.

Patrick M. Rooney is Director of Research at The Center on Philanthropy at Indiana University and Professor of Economics and Philanthropic Studies at Indiana University-Purdue University at Indianapolis. E-mail: rooney@iupui.edu Eugene R. Tempel is Professor of Higher Education and Philanthropic Studies, Indiana University-Purdue University at Indianapolis, and Executive Director of The Center on Philanthropy at Indiana University.
}

Journal for the Scientific Study of Religion (2007) 46(2):217-232 
economics terminology) rather than substitutes for each other. ${ }^{1}$ However, there is across-time evidence suggesting that giving and involvement are substitutes (Gruber 2004).

We present new across-time evidence about giving and involvement patterns: a pattern that describes the prewar cohort (born 1924-1938) as they aged, and a pattern that compares the baby boom cohort (born 1951-1965) in middle adulthood to the middle adulthood prewar cohort. Our interpretation of the patterns rests on two points. First, if recent changes in religious giving reflect an involvement decline then little if any giving decline should be seen among the prewar cohort as they aged from middle adulthood to their senior years. The reason is that on average religious practices are established by middle adulthood with much less change thereafter (e.g., see Argue, Johnson, and White 1999; Hoge, Johnson, and Luidens 1994:8-9; Spilka et al. 2003:348). Rather, if the giving changes reflect an involvement decline the pattern should be seen in the baby boom. Second, if giving changes reflect an involvement decline then changes in giving should parallel changes in involvement. Not only should the parallel be apparent when examining involvement changes among all families, but the parallel should also follow the distinct involvement declines among Catholics and Protestants.

To describe giving patterns we use data from the 1974 National Study of Philanthropy (Morgan 1977) and the 2001 Center on Philanthropy Panel Study (Wilhelm et al. 2001, 2002), and to Q1 describe involvement we use religious service attendance data from the 1972 to 2002 General Social Survey (Davis and Smith 2002). We obtain three main results. First, the prewar cohort's religious giving increased as they aged in that their giving increased faster than their income. In contrast, the baby boom's religious giving is less than expected based on an extrapolation of the prewar cohort's middle adulthood religious giving. Second, these giving patterns are paralleled by attendance patterns: the prewar cohort's attendance increased as they aged, but the baby booms attendance in middle adulthood is less than the prewar cohort's middle adulthood attendance. Further, the changes in baby boomer religious giving compared to the prewar cohort are different among Catholics and Protestants, and the giving differences are in parallel with the different changes in Catholic/Protestant identification and attendance. Third, giving to other purposes has not increased faster than income growth either as the prewar cohort aged or in the middle adulthood comparison of the baby boom to the prewar cohort; this undercuts a diversion explanation of changes in religious giving.

\section{BACKGROUND}

Cross-sectional data indicate that at a point in time, older people give more to religious organizations than younger people, both in dollars and as a percentage of income (see Hoge and Yang 1994, and the references on Hoge 1994:107). However, point-in-time evidence cannot be used to infer either that people give more as they age, or that the current young are giving less now than the current old did in the past. For example, Steinberg and Wilhelm (2003) find using the Center Panel that in 2000 a lower percentage of the baby boom cohort gives to religious organizations compared to the prewar cohort (51 versus 62 percent), but this does not necessarily indicate a financial crisis in American religion-it may be that a lower percentage of the prewar cohort gave to religion when they, too, were in middle adulthood. Moreover, Zech's (2000) point-in-time evidence gathered from loyal and active church members paints a mixed picture of religious giving: compared to the prewar cohort, baby boomers in some denominations are giving less (mainline Protestants), but baby boomers in other denominations are giving about the same (evangelical Protestants and Catholics). However, in addition to not being able to tell us how the baby boom today compares to the prewar cohort when they, too, were in middle adulthood, the evidence from loyal and active members cannot tell us about religious giving in the nation as a whole. 


\section{FIGURE 1}

\section{RELIGIOUS GIVING AS A PERCENTAGE OF PERSONAL INCOME}

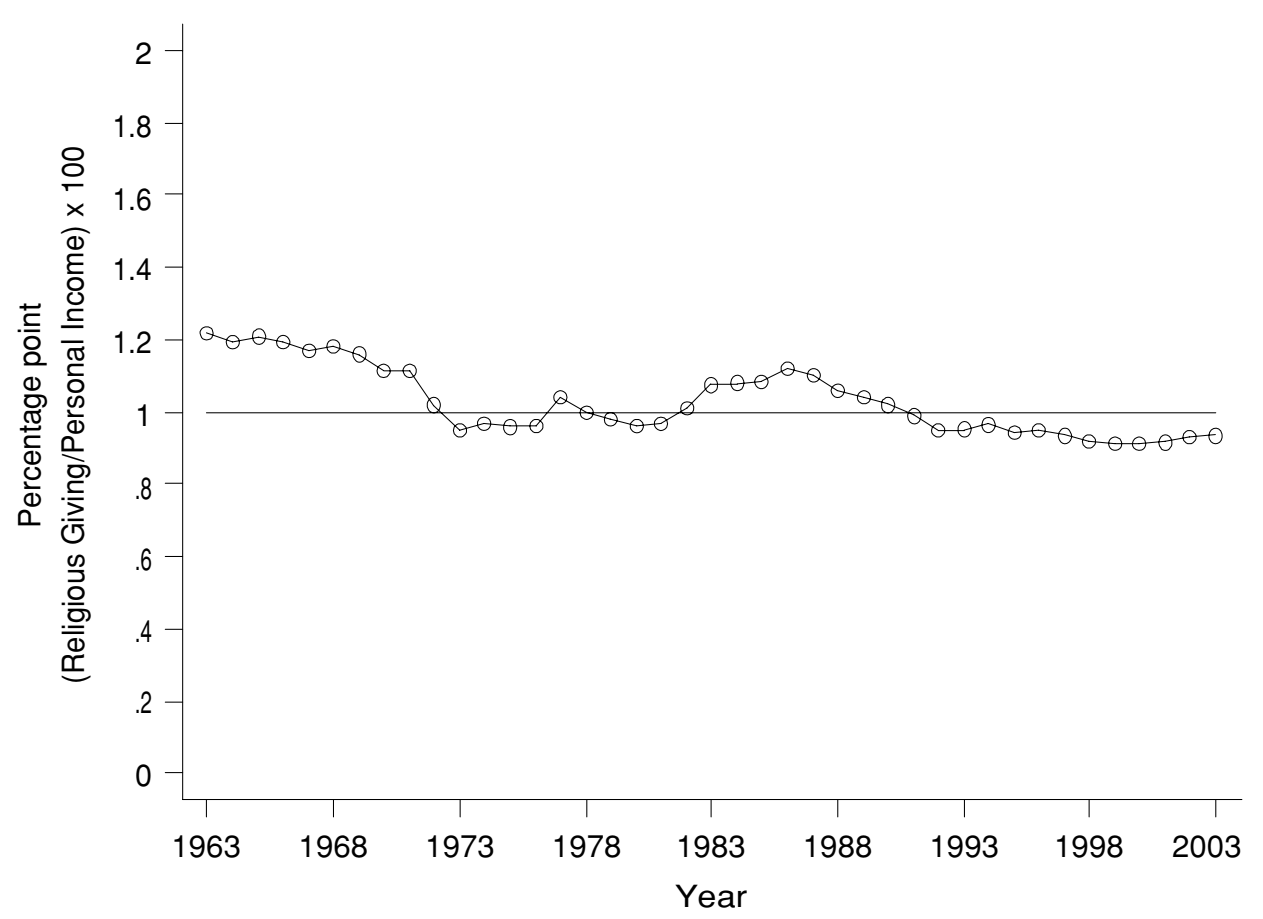

Indeed, it is hard to find evidence of a financial crisis in American religion in the national trend. Figure 1 plots religious giving as a percentage of personal income from 1963-2003 using estimates of religious giving and data on personal income from Giving USA (2004:222, 225). True, a decline in religious giving as a percentage of personal income is noticeable starting from the beginning of the period as a reference point (in 1963 the percentage was 1.2 and in 2000 it was 0.9), but not starting from the early 1970s when the prewar cohort had entered their middle adult years (the percentage was also 0.9 in 1973). ${ }^{2}$

The flat national trend since the early 1970s could be masking underlying change going on within the cohorts that make up the population. The flat trend cannot be used to determine whether the prewar cohort has been sustaining, in their senior years, the level of religious giving initiated in their middle adult years. Similarly, the flat trend cannot be used to determine whether the baby boom's religious giving in 2000 differs from what the prewar cohort gave in 1973.

However, the religious life of baby boomers does differ from the prewar cohort's religious life in other ways. The religious life of baby boomers differs in terms of religious exploration (Roof 1993), importance placed on institutions and institutional religion (Roof 1993:41; Davidson et al. 1997), individualism and pluralism (Hoge, Johnson, and Luidens 1994), denominational loyalty, and emphasis on religious programs that bring satisfaction (Hoge et al. 1996). Among Catholics, the religious life of baby boomers differs because their formative years were during the changes leading up to and following the Second Vatican Council (Davidson et al. 1997).

In contrast to the flat religious giving trend, data from the General Social Survey show slightly declining attendance at religious services in the 1970s and 1980s (e.g., Chaves 1989). Whether these declines are attributed to age, period, or cohort effects depends upon the identification assumptions one makes (see Chaves 1989, 1991; Firebaugh and Harley 1991). We find more compelling the assumptions that ultimately attribute attendance decline to younger cohorts, and 
in addition there is other evidence suggesting younger cohorts attend less frequently (e.g., see Hoge et al. 1994:7-8; Presser and Stinson 1998: Table 4).

\section{Data AND Methods}

We use the 1974 National Study of Philanthropy to measure giving in calendar year 1973. The National Study consists of two surveys: one survey conducted by the University of Michigan's Survey Research Center (SRC) and the other by the Census Bureau. We use the SRC survey because it, unlike the Census survey, includes questions about religious affiliation. ${ }^{3}$

The National Study is distinguished from other giving surveys by its over-sampling of highincome households. The Survey Research Center obtained a high-income over-sample by oversampling high-income geographical areas and by over-sampling respondents either older than 25 years or with a college education. Over-sampling high-income households is desirable because the distribution of giving — even religious giving — is very skewed (Iannaccone 1997). Because of skewness there is the potential to underestimate average giving if the survey does not adequately measure the top of the giving distribution.

We use the 2001 Center on Philanthropy Panel Study — a module within the Panel Study of Income Dynamics (PSID) — to measure giving in calendar year 2000. ${ }^{4}$ Even though the Center Panel does not contain a high-income over-sample, it does the best job of all other recent giving surveys in measuring giving at the top of the distribution (Wilhelm 2006a). Hence, the use of the Center Panel is crucial because other recent giving surveys would bias the results toward showing a decline in giving relative to the 1974 National Study simply because the other surveys underestimate giving at the top. ${ }^{5}$ In contrast, the Center Panel's and the National Study SRC survey's conditional giving distributions - the distributions excluding all those who do not give-match very closely: Figure 2 shows that, with the exception of the 99th percentile, the top percentiles from both surveys are nearly identical. ${ }^{6}$

\section{FIGURE 2
TOP PERCENTILES: CENTER PANEL AND NATIONAL STUDY}

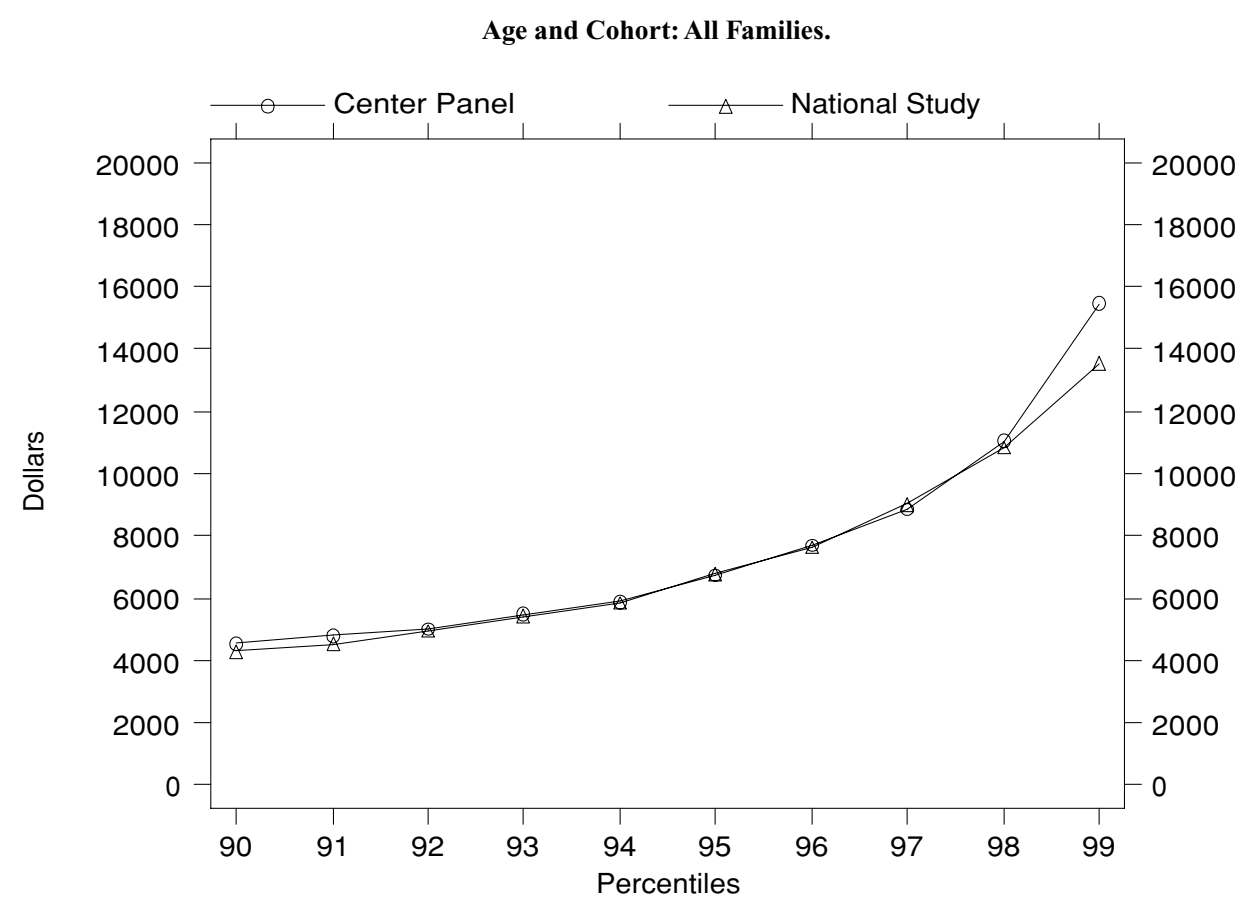


The National Study's giving data are in 1973 dollars. To make the National Study data comparable to the Center Panel data in Figure 2 and throughout the paper, giving in 1973 dollars must be adjusted to 2000 levels. A sensible adjustment should account for both inflation and the 1973-2000 real growth in resources from which charitable gifts are made. We adjust 1973 giving from the National Study to reflect what the giving would have been in 2000 had it increased proportionally with income growth. This adjustment means that our results are about giving as a percentage of income even though to ease interpretation we present the results in terms of dollar amounts. Figure 1 accomplishes the same kind of adjustment by expressing giving as a percentage of personal income. ${ }^{7}$

To capture both inflation and real resource growth we multiply the 1973 dollar amounts from the National Study by the growth in household income (in nominal dollars) over 1973-2000. For example, when we compare 2000 estimates of all households' giving to 1973 estimates of all households' giving (as we do in Figure 2) we multiply the 1973 estimates by the growth in national household income over 1973-2000, a factor of 4.69. When we compare 2000 estimates of baby boom households' giving to 1973 estimates of prewar households' giving, we multiply the 1973 estimates by the growth in national income for households aged 35-49 over 1973-2000, a factor of 4.49. Hence, when we compare the 2000 baby boom giving to the 1973 prewar giving multiplied by 4.49 we are asking, "What would the giving of 35-49 year olds be in 2000 if the giving of 35-49 year olds from 1973 was extrapolated forward based on the income growth experienced by $35-49$ year olds?"8

If we were to use an analogous extrapolation to study the prewar households' giving as they aged-multiplying the 1973 estimates by the average income of 62-76 year olds in 2000 divided by the average income of 35-49 year olds in 1973-the adjustment factor would be only 3.06. We think this adjustment factor is too low to adequately account for the improvement in the average economic well-being of the prewar cohort over 1973-2000 because the average income of 6276 year olds in 2000 (the adjustment factor's numerator) is mostly income during retirement and that underestimates average economic well-being during retirement. In fact, the 3.06 adjustment factor is lower than a pure inflation adjustment (a factor of 3.88), so using the 3.06 factor would imply that the economic well-being of the prewar cohort worsened as they aged. Therefore we use the average income of the nearest, nonretired cohort (55-64 year olds in 2000) to estimate the economic well-being of 62-76 year olds in the numerator of the adjustment factor; this leads to an adjustment factor of 3.96. Because even this factor may be too low (3.96 is not much larger than a pure inflation adjustment), in the conclusion we will discuss how the prewar cohort's results would differ if a larger adjustment factor were used—in short, the results do not differ much.

Giving measured in both the National Study and Center Panel is separated into religious giving and secular giving. We measure religious giving in the National Study by using the names of organizations to which the respondent made his/her four largest gifts. The organization names were sorted by the Survey Research Center into types: religious, combined appeals (e.g., United Way), community, health, education, social welfare, culture, public affairs, environment, international aid, private foundation, and other. Churches and church groups were assigned the "religion" type, but religiously affiliated organizations whose primary purpose was not religious (e.g., religious grade schools, Catholic Charities) were sorted into one of the latter 12 types. Our 1973 religious giving variable is all gifts to religious organizations; our secular giving variable is all gifts to the other 12 organization types. ${ }^{9}$

In the Center Panel giving is queried separately by type of purpose. Respondents were asked about giving "for religious purposes or spiritual development, for example to a church, synagogue, mosque, TV or radio ministry;" this forms our 2000 religious giving variable. When asked about religious giving respondents are instructed not to report giving to "schools, hospitals, and other charities run by religious organizations" because this giving will be queried with subsequent questions about giving for combined purposes, for poverty relief, health, education, youth and 
family services, culture, communities, environment, international aid, and other purposes. We combine giving to all these subsequent purposes to form our 2000 secular giving variable.

Thus the National Study and the Center Panel achieve a similar split of total giving into religious and secular parts. We use the label "secular" even though some of the giving included in this variable is going to religiously affiliated organizations whose primary purpose is something besides worship or spiritual development.

We use the National Study to measure the prewar cohort's giving in middle adulthood (ages 35 to 49 in 1973, $\mathrm{n}=574$ ). We use the Center Panel to measure the prewar cohort's giving in their senior years (ages 62 to 76 in 2000, $\mathrm{n}=577$ ) and the baby boom's giving in middle adulthood (ages 35 to 49 in 2000, $\mathrm{n}=1,527$ ).

\section{Methods}

We estimate patterns in average family giving over time. The averages are weighted using the weights from the two surveys. The National Study weights adjust for the effect of the highincome over-sample when estimating population averages. The Center Panel uses the PSID's "family weights;" the weights adjust for attrition and mortality since the PSID's beginning in 1968. Averages from the Center Panel are very similar whether weights are used or not.

The methods must handle two data issues. First, a respondent in the National Study who said that he gave something but that altogether his giving was $\$ 100$ or less was asked no further questions to pin down the amount given. For such respondents all we know is that they gave between $\$ 1$ and $\$ 100$ (or $\$ 4.69$ and $\$ 469$ in income-growth adjusted 2000 dollars); we set such gifts to $\$ 4.69$ in 2000 dollars. To make the Center Panel data comparable, we artificially imposed this same lack of information about gifts under $\$ 469$; in particular we reduce all amounts in the Center Panel under $\$ 469$ to $\$ 4.69$. This has the effect of lowering the average gift in the Center Panel by about $\$ 50$, but has no effect on the 60th and higher percentiles. Hence, we use data patterns at higher percentiles as a check on patterns in the averages.

Second, we drop one observation from the Center Panel prewar cohort whose secular giving is clearly an outlying amount. ${ }^{10}$ If instead we include this observation, on its own the influential observation alters the estimated pattern of average secular giving of the prewar cohort as they aged to indicate much faster growth than income. Unlike this estimate of the average, estimates of higher percentiles are robust against outliers, and estimates of higher percentiles do not indicate faster-than-income growth in secular giving, even when the influential observation is included.

Finally, we do not include respondents who immigrated to the U.S. after 1973 in our analysis so that changes in the prewar cohort as they aged, and between the prewar cohort and baby boom in middle adulthood, are not affected by the addition of immigrants to the cohorts.

\section{Religious Identification and Attendance at Religious Services}

We use the 1972-2002 General Social Survey to describe religious identification and attendance at religious services for the prewar cohort over 1972-75 and the prewar and baby boom cohorts in 1998-2002 (we use additional years near 1973 and 2000 to increase the sample size). ${ }^{11}$ Chaves and Stevens (2003) review evidence that more respondents report attending religious services weekly than who actually attend. Smith (1998) concludes that the overreporting is due to social desirability, telescoping (people reporting nearly weekly attendance as weekly), and respondents' broad interpretations of attendance at "religious services" to include more than worship services (e.g., attendance at Bible studies, choir practices, fellowship meetings).

Overreported attendance is not a problem if the survey responses are intended to measure religious involvement, broadly defined. Chaves and Stephens go further, speculating that respondents may broaden the attendance question to be a question about religious identity and that the 
overreports may be accurate reports of the respondents' "identities as religious individuals who attend services more or less regularly, even if not weekly" (2003:90).

For our purposes we need the attendance question to serve as a measure of broad religious involvement. This mitigates concern that would arise if it were important for our purposes that the attendance measure literally be a measure of weekly attendance. Further, to mitigate potential telescoping problems we use the percentage of respondents who say they attend religious services once every two weeks or more. The patterns we find are the same if instead we use all the response categories to impute a continuous attendance variable.

\section{Results}

Table 1 presents our results for all families regardless of their religious identification, including those whose identification is "none." The table has three major headings to describe total, religious, and secular giving. Within each heading are three columns: the first is for the prewar cohort in 1973, the second column is for the prewar cohort in 2000, and the third is for the baby boom cohort in 2000 .

The first row presents estimates of the prewar cohort's average giving as they aged. The estimated average total giving of the prewar cohort in middle adulthood is $\$ 1,424$. Recall, this is an estimate of what the prewar cohort's giving would have been in 2000 had it grown at the same rate as their income. The prewar cohort's actual giving in 2000 is $\$ 1,609-\$ 185$ more than would have been expected on the basis of their 1973-2000 income growth. Almost all of this $\$ 185$ is accounted for by religious giving. Estimates of the prewar cohort's average religious giving are $\$ 874$ in 1973 and \$1,040 in 2000—indicating religious giving grew more than would have been expected based on the prewar cohort's income growth. Secular giving by the prewar cohort- $\$ 550$ in 1973 and \$568 in 2000 — indicates growth essentially in line with income.

Baby boomer average giving during their middle adult years is $\$ 1,371$. This is $\$ 244$ less than the $\$ 1,615$ calculated by extrapolating the prewar cohort's middle adulthood giving from 1973 forward to 2000 using income growth among 35-49 year olds. In this sense, baby boomer giving in middle adulthood is "less-than-expected." The baby boomers' religious giving is $\$ 789$, about $\$ 200$ less-than-expected compared to the prewar cohort in middle adulthood. Secular giving is about $\$ 40$ less-than-expected. Hence, most of the baby boom's less than expected giving is due to their levels of religious giving.

Patterns similar to those seen in the averages emerge when looking at estimates of the top percentiles in the remaining rows of Table 1. The similar patterns in averages and percentiles suggest that the patterns in averages are not substantially altered by our handling of the Center Panel's gifts under $\$ 469$. For example, in 2000 the top percentiles of the prewar cohort's religious giving are all larger than would have been expected based on their income growth applied to the 1973 percentiles, again indicating growth faster than income. In contrast, the baby boom's 75th and 90th percentiles ( $\$ 500$ and $\$ 2,400$ ) are noticeably less-than-expected compared to the 1973 prewar cohort, whereas the 95th and 99th $(\$ 4,500$ and $\$ 9,000)$ are not. This is the first hint that the giving change reflects an involvement change: the less-than-expected religious giving is not due to the baby boom's large givers (who compare fairly closely to the prewar cohort's large givers during middle adulthood), but to more baby boomers - the bulk of the cohort that is below the 90th percentile-making smaller gifts.

Baby boomer giving is "less-than-expected" not because they have lower resources from which to give. We used regression methods and an Oaxaca decomposition (Greene 2003:53-54) to decompose the 1973-to-2000 change in giving into 1973-to-2000 changes in income and wealth levels and 1973-to-2000 changes in the amounts given at each level of income and wealth (detailed regression and decomposition results are available upon request). The decomposition indicates that had it not been for the baby boom's increased wealth (compared to the prewar cohort's wealth in middle adulthood), the baby boom's religious giving would have been even lower ( $\$ 711$ instead 


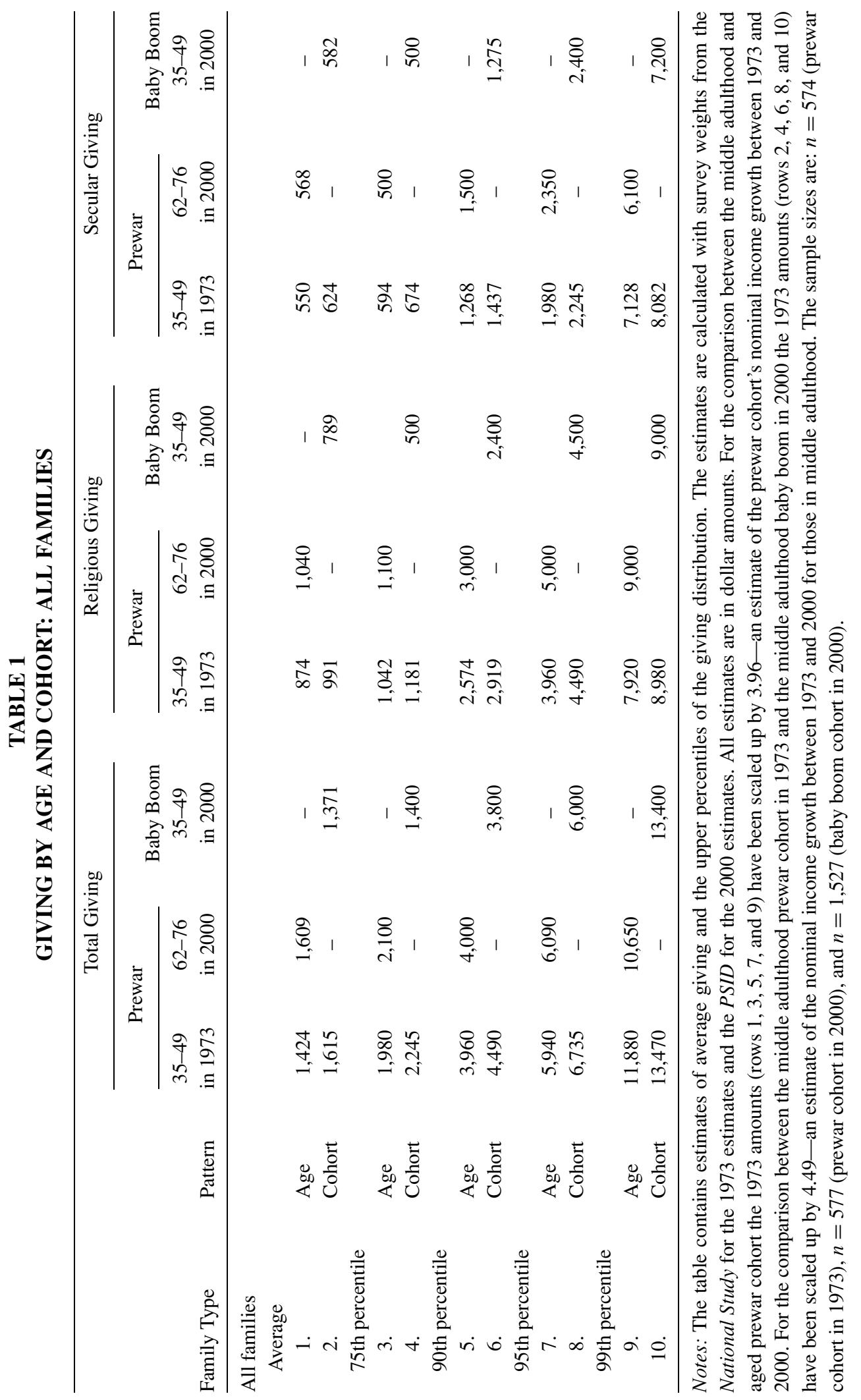


of \$789) and their secular giving much lower (\$463 instead of \$582). Hence, the baby boom's less-than-expected giving would likely have been much more severe had it not been for their increased wealth. Similarly, the prewar cohort's higher wealth in their senior years (compared to the wealth they held in middle adulthood) can account for the more-than-expected growth in the prewar cohort's religious giving as well as the in-line-with-income growth in their secular giving. The decomposition indicates that if the prewar cohort's wealth in 2000 had remained the same as it was in 1973, their predicted average religious giving would be $\$ 614$ (instead of \$1,040) and predicted average secular giving would be $\$ 305$ (instead of \$568).

In summary, the estimates suggest that the religious giving of the prewar cohort grew faster than their income growth as they aged, but that prewar secular giving grew at the same rate as their income. The baby boom is giving less-than-expected to religion compared to what the prewar cohort was giving in middle adulthood. Baby boomer secular giving is a little less-than-expected compared to the prewar cohort's middle adulthood giving, but clearly not to the same extent as their religious giving. Baby boom giving would have been even lower had it not been for their increased wealth.

\section{Giving Patterns among Catholics and Protestants}

Table 2 presents the giving results separately for Catholic and Protestant families. For Catholic families in the prewar cohort both religious and secular giving grew faster than income (row 1). For Protestant prewar families (row 3) religious giving grew much faster than income, hence faster than the religious giving of the Catholic prewar cohort. The Protestant prewar cohort's secular giving grew slower than income, unlike the secular giving of the Catholic prewar cohort.

Baby boom Catholic families are giving less-than-expected to religion compared to what prewar Catholic families were giving in middle adulthood: around \$160 less (row 2). Catholic baby boomer secular giving is also less-than-expected compared to prewar Catholics in middle adulthood. A different pattern emerges for Protestant baby boomers (row 4): religious giving is less-than-expected compared to Protestant prewar cohort families, but the difference is smaller than seen in the comparison of prewar and baby boom Catholics. The different Catholic-Protestant patterns are more striking in percentage terms (21 percent less-than-expected for Catholics and only 8 percent less for Protestants). Protestant baby boomer secular giving is in line with an extrapolation of the Protestant prewar cohort's secular giving in middle adulthood.

\section{Identification and Involvement Patterns}

Table 3 presents identification and involvement patterns. Row 1 shows declines in the percentage of respondents identifying themselves as Catholic. The declines are for both the prewar cohort as they aged (from 27 to 22 percent) and between the cohorts ( 24 percent of the middle adulthood baby boomers identify as Catholic). Row 2 shows a different Protestant identification pattern: an increase in the percentage of the prewar cohort identifying as Protestant (from 64 to 68 percent) but a decline between the cohorts ( 57 percent of the middle adulthood baby boomers identify as Protestant).

Rows 3 through 5 present the involvement patterns, both for all families and separately for Catholic and Protestant families. Among all families in the prewar cohort, the percentage attending religious services every other week or more increased as they aged (from 48 to 52 percent). In contrast, the percentage of all families in middle adulthood attending biweekly or more decreased between cohorts (to 38 percent).

Once more the patterns for Catholics and Protestants are different. The attendance of Catholic prewar families has not changed much as they aged: 62 percent attended biweekly or more in middle adulthood and 63 percent attend biweekly or more in their senior years, but the percentage of Catholic middle adulthood baby boomers attending biweekly or more is only 41 percent, 


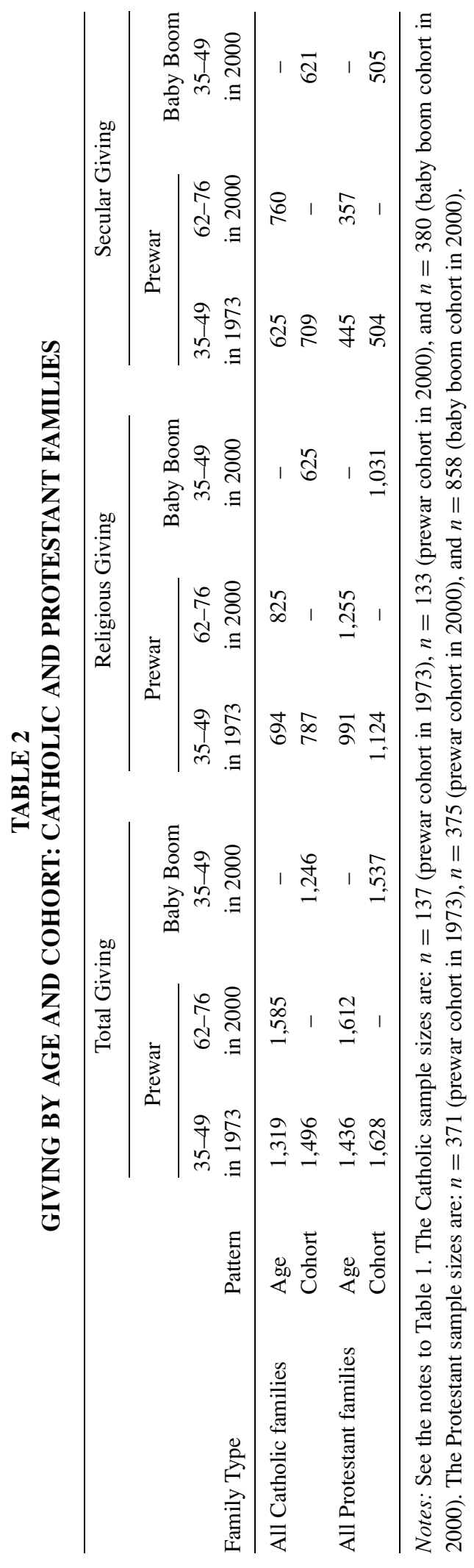


TABLE 3

RELIGIOUS IDENTIFICATION AND INVOLVEMENT BY AGE AND COHORT

\begin{tabular}{lccc}
\hline & \multicolumn{2}{c}{ Prewar } & Baby Boom \\
\cline { 2 - 3 } Variable & $35-49$ in 1973 & $62-76$ in 2000 & $35-49$ in 2000 \\
\hline Identification & & & \\
$\quad$ Catholic & 27 & 68 & 24 \\
$\quad$ Protestant & 64 & 52 & 57 \\
Involvement-attending biweekly or more & 48 & 63 & 38 \\
$\quad$ All families & 62 & 55 & 41 \\
$\quad$ Catholic families & 47 & & 47 \\
$\quad$ Protestant families & & & \\
\hline
\end{tabular}

Notes: All entries in the table are percentages. To facilitate comparison of this table with Tables 1 and 2 we have retained the column headings used in the earlier tables even though in the present table data from additional years are used: column 1 contains 1972-1975 data for the prewar cohort; column 2 contains 1998, 2000, and 2002 data for the prewar cohort; and column 3 contains 1998, 2000, and 2002 data for the baby boom. The sample sizes are: $n=1,545$ (prewar cohort in 1972-1975), $n=1,076$ (prewar cohort in 1998-2002), and $n=2,405$ (baby boom cohort in 1998-2002). In 2000 only respondents born in the U.S. are included.

dramatically less. In contrast, the attendance of Protestant prewar families increased as they aged: 47 percent attended biweekly or more in middle adulthood and 55 percent attend biweekly or more in their senior years. And unlike Catholic boomers, the percentage of Protestant middle adulthood baby boomers attending biweekly or more is the same as Protestant prewar families in middle adulthood: 47 percent. $^{12}$

\section{Discussion And Conclusion}

The results indicate that religious giving of the prewar cohort grew faster than their income as they aged-for all prewar families, for Catholic prewar families, and for Protestant prewar families. This conclusion would be qualified, but only somewhat, if a larger factor had been used to adjust the 1973 giving of the prewar cohort to 2000 levels. If the 4.69 factor had been used (capturing 1973-2000 income growth of the nation as a whole) the results would no longer show faster-than-income growth as the prewar cohort aged, but still the results would not show a decline: the prewar cohort's religious giving extrapolated to 2000 using the 4.69 factor is $\$ 1,035$ (compared to the actual \$1,040) for all families, $\$ 822$ (compared to the actual \$825) for Catholic families, and $\$ 1,174$ (compared to $\$ 1,255$ ) for Protestant prewar families. Hence, any decline in religious giving since the early 1970 s is not due to the prewar cohort. ${ }^{13}$

A decline in religious giving is due to the baby boom cohort: they give less-than-expected based on an extrapolation of what the prewar cohort was giving in their middle adult years. Involvement follows a parallel pattern: an increase in religious involvement among the prewar cohort as they aged, but the baby boom cohort is markedly less involved. This is across-time evidence that changes in giving reflect changes in involvement.

If this interpretation is correct the giving patterns should parallel the distinctly different identification and involvement patterns of Catholics and Protestants. The Catholic pattern is a small drop (three percentage points) in the percentage of baby boomers identifying as Catholic (compared to the prewar cohort in middle adulthood), but among these Catholic boomers, a striking attendance decline. The Protestant pattern is different: a larger drop (seven percentage points) in the percentage of baby boomers identifying as Protestant, but among Protestant boomers 
attendance is the same as prewar Protestant families in middle adulthood. The religious giving patterns parallel this difference. Religious giving among Catholic baby boomers is much less than expected. Protestant baby boomers are giving less than expected too, but not to the same degree as Catholic baby boomers.

The results suggest that the different prewar-to-baby boom cohort patterns in giving and attendance for Catholics and Protestants are to some extent caused by selection. Less involved Catholics give less-than-expected and attend less, but still claim a Catholic identity; the set of Catholics therefore contains a mixture of involved and not involved people. Less involved Protestants stop identifying themselves as Protestant, selecting themselves out of the set of people surveys identify as Protestant. This implies that the set of people that surveys identify as Protestant contains relatively more people who are involved. ${ }^{14}$

While a selection explanation is consistent with how the across-time cohort change among Catholics in religious giving differs from the across-time cohort change among Protestants in religious giving, selection does not seem to explain much of the point-in-time difference in Catholic religious giving compared to Protestant religious giving that has been well-established in previous research. For instance, Hoge et al. (1996:41) obtained a sample of "disproportionally loyal and active [church] members"- a disproportionally large 79 percent of the sample's Catholics said they attended services once a week or more (see Table A-6) - but nevertheless a large pointin-time Catholic-Protestant religious giving difference remains. ${ }^{15}$

Hoge et al. conclude that the main factor correlating with the point-in-time difference in Catholic-Protestant religious giving is a difference in theological belief. They also present evidence that less emphasis on giving explains some of the lower Catholic giving (1996:94). In other work, Zaleski and Zech (1994) conclude that the dramatically larger sizes of Catholic parishes compared with Protestant congregations also explains lower Catholic giving. It is possible that these factors, correlated with lower Catholic giving at a point-in-time, might also explain the across-time less-than-expected religious giving of Catholic baby boomers, but it is unlikely that either across-time change in Catholic's theological beliefs (survey evidence indicates that core Catholic beliefs have not changed among newer generations; see D'Antonio 2005) or lessening emphasis on giving in parishes (if anything, emphasis on giving has increased) provide much of the explanation. However, North American parish sizes have grown dramatically (33 percent between from 1975 to 2000; see Froehle and Gautier 2003:76), and this could explain some of the less-thanexpected religious giving of Catholic baby boomers. It would be interesting to see if the giving of Catholic baby boomers has fallen farther below expectations in parishes that have grown more rapidly.

If the selection explanation has any merit in explaining how the across-time cohort change among Catholics in religious giving differs from the across-time cohort change among Protestants, the explanation should work for the secular giving patterns as well. It does. The secular giving of Catholic boomers is less-than-expected compared to the Catholic prewar cohort in middle adulthood, while the secular giving of Protestant boomers is in line with the Protestant prewar cohort in middle adulthood. In contrast to selection, it is not clear how larger parish sizes (the one factor that is both an explanation of the point-in-time lower Catholic religious giving as well as a possible explanation of the across-time less-than-expected Catholic religious giving) can also explain the less-than-expected secular giving of Catholic baby boomers. ${ }^{16}$

None of the results support the argument that less-than-expected religious giving may be due to more giving being diverted toward secular purposes. Indeed, one result suggests the diversion went the other way: the Protestant prewar cohort's religious giving grew faster than income while their secular giving grew a little slower than income.

Readers should keep two qualifications in mind while thinking about the results. First, the sample sizes in the National Study and Center Panel, though not small, are usually not large enough to provide the precision necessary to conclude that any single change between estimates is statistically significant. ${ }^{17}$ The argument we have made- that changes in giving reflect changes 
in involvement-is not built on the statistical significance of any one change, but rather on how all of the changes together suggest a unified interpretation.

Second, although the Center Panel is the only recent survey that measures giving at the top of the distribution well enough to even attempt describing giving patterns based on a comparison with the National Study SRC survey, it should be kept in mind that both surveys have fewer observations of giving above the 90th percentile than appear in tax data. Because of this it is possible in principle, though we think not likely, that giving patterns above the 90th percentile would counter the patterns we have described. We think it not likely because (taking the prewar-baby boom religious giving comparison as an illustration) a counter-pattern above the 90th percentile would imply a sizable minority of baby boomers giving so much more than expected to religion that it would escape both the anecdotal statements of church leaders nor media reports. To our knowledge there have been no such statements or reports.

Our conclusion that religious giving and involvement change together across time is similar to the result from numerous point-in-time studies that giving and involvement are positively correlated (e.g., Clain and Zech 1999; Forbes and Zampelli 1997; Iannaccone 1997; Olsen and Caddell 1994; Sullivan 1985). The across-time and point-in-time results suggest that people for whom religiosity is very important - whether it is belief in after-life rewards, closeness to God, enjoyment of worship services, approbation of fellow adherents, or other dimensions of religious experience — both do more religious giving and more frequently attend religious services. Simply put, our results indicate that the giving-attendance connection found in numerous pointin-time studies also holds for cohort change between the prewar cohort and the baby boom. In this interpretation the baby boom's giving less-than-expected and less frequent attendance are indicators of their declining religiosity, at least the kind of religiosity expressed by religious giving and attending. ${ }^{18}$

The present results are of interest for several reasons. To our knowledge, the results are the first to describe the giving of a cohort as it ages and the first to compare two different cohorts when they were the same age. Second, the results provide evidence that generational change is at the foundation of recent changes in American religious giving, similar to our results and the results of others that generational change is at the foundation of recent changes in American religious involvement. Third, differences between Catholics and Protestants in their giving and involvement patterns across time are to some extent caused by selection. Selection is likely to become a more important explanation of Catholic-Protestant differences because Generation X Catholics are continuing to identify as Catholics while reducing their involvement (Davidson et al. 1997). Most important, the results offer evidence that changes in American religious giving across time reflect changes in involvement.

\section{ACKNowledgments}

An early version of this article was presented at the Independent Sector 2003 Spring Forum. Thanks go to David Sikkink for comments on the early version, to Mark Chaves, Bill Enright and Chuck Zech for helpful conversations, and to three anonymous JSSR referees and Rhys Williams for their suggestions. Thanks go to the Lake Family Institute on Faith and Giving for providing several settings in which to exchange ideas about this work. We also thank Melissa Brown for sharing data from Giving USA and Rob Bandy, David Fleischhacker, and Kiyoko Kamimura for excellent research assistance. Finally, we are especially grateful to Atlantic Philanthropies, whose generous financial support made the collection of the 2001 Center on Philanthropy Panel Study possible.

\section{Notes}

1. See Clain and Zech (1999:940) and the additional references therein. Clain and Zech also argue that giving crises are involvement crises.

2. The results are similar if either disposable personal income or gross domestic product is used as the denominator. It is possible that Giving USA overestimates religious giving (see Chaves 1999:176-77), but Brown, Harris and Rooney 
(2004) calculate religious giving for 2002 using three different methods (including the method used by Giving USA) and find close agreement across methods. Ronsvalle and Ronsvalle (1999) report declining per member religious giving as a percentage of per capita disposable income since the early 1970s, but it may be that their use of giving to a list of 29 denominations misses increases in giving to other denominations not on their list.

3. The National Study's SRC sample was drawn using an area probability design. The response rate was 75 percent, and heads-of-household were interviewed. See Morgan, Dye, and Hybels (1979) for further information about the study.

4. The $P S I D$ 's nationally representative sample was drawn in 1968 using stratified multistage selection (the $P S I D$ also contains a 1968 low-income over-sample and a 1997 immigrant refresher sample, neither of which we use). The 1968 response rate was 76 percent, and subsequent studies indicate that the PSID remains representative (e.g., see Fitzgerald, Gottschalk, and Moffitt 1998). Most interviews are conducted with male heads-of-household. See Hill (1992) for further information about the PSID

5. It might be argued that the Center Panel overestimates giving, but Wilhelm's (2006b) finding that the Center Panel matches the Internal Revenue Service's distribution of giving through the 90th percentile indicates not.

6. We conducted chi-square tests for differences between the percentiles based on the distribution of the Center Panel relative to the National Study (see Handcock and Morris 1999 for a description of relative distributions). When tested separately, all the differences between percentiles were insignificant at ten percent. However, joint tests (say, of the equality of all ten pairs of percentiles) do reject equality; despite this ability to statistically distinguish between the distributions, the point is that with the exception of the 99 th, differences between percentiles are quantitatively small.

7. Adjusting by inflation alone is not sensible because the costs of running a church (or any organization) rise due to real reasons as well as inflation. For example, consider a church whose members pay their pastor in 2000 the same as they did in 1973 adjusted for inflation but not real income growth—even though the members of the church enjoyed real growth in their own incomes. Most observers would conclude that, relative to the resources available to members, the members are paying their pastor less generously in 2000 than in 1973.

8. We calculate the adjustment factors using tables from the U.S. Census Bureau (Table H-3: Mean Income Received by Each Fifth and Top 5 Percent of Households (All Races), 1967-2001 and Table H-10: Age of Head of Household: All Races by Median and Mean Income of Households (All Races), 1967 to 2001; see http://www.census.gov/hhes/ income/histinc/h03.html and h10.html).

9. An alternative would be to use the question that asks about the percentage of all gifts made to religious activities; this question indicates a slightly higher amount going toward religious activities (Morgan, Dye, and Hybels 1979). Hence, our calculations based on the four largest gifts may slightly understate religious giving in 1973 and, if so, overstate increases (and understate decreases) between 1973 and 2000.

10. The family gave $\$ 490,000$ toward health purposes, an amount about ten times higher than the next highest secular gift in the Center Panel. In contrast, the highest amount given to secular purposes in the National Study is only 70 percent higher than the next highest gift: $\$ 159,460$ versus $\$ 93,800$.

11. The General Social Survey uses a stratified multistage design. Response rates are 70 percent or higher. Interviews are conducted with a randomly selected adult (18 years or older) within the household. See Davis and Smith (1992) for further information.

12. Others have reached similar conclusions about identification and attendance patterns; see Putnam (2000:75-76) and Smith and Kim (2005).

13. To back up this conclusion we also need to argue that the prewar cohort at ages $62-76$ (in 2000) is giving no less than the 1897-1911 cohort gave when they were aged 62-76 (in 1973). This is the case: the prewar cohort's religious giving in $2000(\$ 1,040)$ is more than would have been expected based on an extrapolation of the 1897-1911 cohort's religious giving (\$834). (The prewar cohort's secular giving $\mathrm{C} \$ 568$-is less than would have been expected based on an extrapolation of the 1897-1911 cohort's secular giving — \$729).

14. Hoge et al. (2001:220) make a similar argument that young adult Catholics like identifying as Catholic but are less attached to Catholic institutions. Olsen and Caddell (1994) also use a selection argument to explain why congregations declining in membership have higher per-member giving.

15. Most of the regression specifications in the previous literature cannot be used to see if differences in attendance explain the point-in-time Catholic-Protestant difference in religious giving, but Iannaccone's (1997, Table 1) regressions indicate that a difference in attendance is not the explanation. When he adds attendance to the independent variables in a giving regression there is very little change in the estimated correlation between Catholic affiliation and giving.

16. It is not even clear that differences in theological beliefs, emphasis on giving, and parish size correlate with CatholicProtestant differences in secular giving at a point in time. Hoge et al. (1996:49) report that average household giving to nonreligious charities by Catholics (\$244) is higher than Assemblies of God (\$141), similar to Baptists and Lutherans (\$220 and \$261), but less than Presbyterians (\$401). Likewise, the point-in-time results in Table 2 suggest that Catholic secular giving is higher than Protestants.

17. For this reason we have not presented standard errors for the changes in estimates as the prewar cohort aged or between the two cohorts. Standard errors for any of the changes in estimates (as well as for the estimates themselves) are available upon request. Three of the estimated changes are statistically significant: the $\$ 244$ and the $\$ 202$ changes in total and religious giving between the prewar and baby boom cohorts and the $\$ 264$ increase in religious giving by prewar cohort Protestants. 
18. This does not imply that if you hold religiosity constant and, say, increase the price of giving by cutting marginal income tax rates, that both giving and attendance would fall together. Gruber (2004) asks the holding-religiosityconstant question and finds that tax rate cuts lower religious giving but raise attendance, as would be predicted by Azzi and Ehrenberg's (1975) production model. Gruber's result taken at face value implies that we would have found even greater attendance declines among baby boomers had it not been for tax cuts over the time period. However, it may be that Gruber's analysis to some degree confounds the tax cuts with generational change: it may be that the prewar cohort received larger tax cuts than the baby boomers (by virtue of the prewar cohort's generally higher incomes over the period) and increased their attendance due to aging while the baby boom reduced their attendance due to a cohort effect. This possibility could be checked by seeing whether the tax-cuts-raise-attendance result holds within the prewar and baby boom cohorts, an interesting topic for future research.

Also note that our results and Gruber's results are based on different sources of variation: our results are based on age variation within a cohort and variation between two cohorts and Gruber's results are based on variation across-time within income groups within states.

\section{REFERENCES}

Argue, Amy, David R. Johnson and Lynn K. Waite. 1999. Age and religiosity: Evidence from a three-wave panel analysis. Journal for the Scientific Study of Religion 38(3):423-35.

Azzi, Corry and Ronald Ehrenberg. 1975. Household allocation of time and church attendance. Journal of Political Economy 83(1):27-56.

Brown, Melissa S., Joseph Claude Harris and Patrick M. Rooney. 2004. Reconciling estimates of religious giving. Mimeo. Indianapolis: Center on Philanthropy at Indiana University.

Chaves, Mark. 1989. Secularization and religious revival: Evidence from U.S. church attendance rates, 1972-1986. Journal for the Scientific Study of Religion 28(3):464-77.

- 1991. Family structure and protestant church attendance: The sociological basis of cohort and age effects. Journal for the Scientific Study of Religion 30(3):501-14.

- 1999. Financing American religion. In Financing American religion, edited by Mark Chaves and Sharon L. Miller, pp. 169-88. Walnut Creek, CA: AltaMira.

Chaves, Mark and Sharon L. Miller, eds. 1999. Financing American religion. Walnut Creek, CA: AltaMira.

Chaves, Mark and Laura Stevens. 2003. Church attendance in the U.S. In Handbook of the sociology of religion, edited by Michelle Dillon, pp. 85-95. New York: Cambridge University Press.

Clain, Suzanne Heller and Charles B. Zech. 1999. A household production analysis of religious and charitable activity. American Journal of Economics and Sociology 58(4):923-47.

D’Antonio, William V. 2005. Generational differences. National Catholic Reporter. On-line: http://ncronline.org/NCR Online/archives2/2005c/093005/093005m.php.

Davidson, James D., Andrea S. Williams, Richard A. Lamanna, Jan Stenftenagel, Kathleen Maas Weigert, William J. Whalen, and Patricia Wittberg. 1997. The search for common ground: What unites and divides Catholic Americans. Huntington, IN: Our Sunday Visitor.

Davis, James A. and Tom W. Smith. 1992. The NORC General Social Survey. Newbury Park, CA: Sage.

Davis, James A. and Tom W. Smith. 2002. General Social Surveys, 1972-2002 [machine- readable data file]/Principal Investigator, James A. Davis; Director and Co-Principal Investigator, Tom W. Smith; Co-Principal Investigator, Peter V. Marsden; Sponsored by the National Science Foundation. -NORC ed.-Chicago: National Opinion Research Center [producer]; Storrs, CT: The Roper Center for Public Opinion Research, University of Connecticut [distributer].

Firebaugh, Glenn and Brian Harley. 1991. Trends in U.S. church attendance: Secularization and revival, or merely lifecycle effects? Journal for the Scientific Study of Religion 30(3):487-500.

Fitzgerald, John, Peter Gottschalk and Robert Moffitt. 1998. An analysis of sample attrition in panel data: The Michigan Panel Study of Income Dynamics. Journal of Human Resources 33(2):251-99.

Forbes, Kevin F. and Ernest M. Zampelli. 1997. Religious giving by individuals: A cross-denominational study. American Journal of Economics and Sociology 56(1):17-30.

Froehle, Bryan T. and Mary L. Gautier. 2003. Global Catholicism: Portrait of a world church. Maryknoll, NY: Orbis Books.

Giving USA. 2004. Indianapolis: The American Association of Fund Raising Counsel Trust for Philanthropy.

Greene, William H. 2003. Econometric analysis, 5th ed. Upper Saddle River, NJ: Prentice Hall.

Gruber, Jonathan. 2004. Pay or pray? The impact of charitable subsidies on religious attendance. Journal of Public Economics 88(12):2635-55.

Handcock, Mark S. and Martina Morris. 1999. Relative distribution methods in the social sciences. New York: SpringerVerlag.

Hill, Martha S. 1992. The panel study of income dynamics. Newbury Park, CA: Sage.

Hoge, Dean R. 1994. Introduction: The problem of understanding church giving. Review of Religious Research 36(2):10110. 
Hoge, Dean R., William D. Dinges, Mary Johnson, and Juan L. Gonzales, Jr. 2001. Young adult Catholics: Religion in the culture of choice. Notre Dame, IN: University of Notre Dame Press.

Hoge, Dean R., Benton Johnson, and Donald A. Luidens. 1994. Vanishing boundaries: The religion of mainline Protestant baby boomers. Louisville: Westminster/John Knox.

Hoge, Dean R. and Fenggang Yang. 1994. Determinants of religious giving in American denominations: Data from two nationwide surveys. Review of Religious Research 36(2):123-48.

Hoge, Dean R., Charles Zech, Patrick McNamara and Michael J. Donahue. 1996. Money matters: Personal giving in American churches. Louisville: Westminster John Knox.

_ 1999. Giving in five denominations. In Financing American religion, edited by Mark Chaves and Sharon L. Miller, pp. 3-10. Walnut Creek, CA: AltaMira.

Iannaccone, Laurence R. 1997. Skewness explained: A rational choice model of religious giving. Journal for the Scientific Study of Religion 36(2):141-57.

Morgan, James N. 1977. A National Study of Philanthropy [machine-readable data file]/Principle Investigator, James N. Morgan; Sponsored by the Commission of Private Philanthropy and Public Needs. Ann Arbor: Institute for Social Research, The University of Michigan.

Morgan, James N., Richard F. Dye and Judith H. Hybels. 1979. Results from two national surveys of philanthropic activity. Ann Arbor: Institute for Social Research, The University of Michigan.

Olsen, Daniel V. A. and David Caddell. 1994. Generous congregations, generous givers: Congregational contexts that stimulate individual giving. Review of Religious Research 36(2):168-80.

Presser, Stanley and Linda Stinson. 1998. Data collection mode and social desirability bias in self-reported religious attendance. American Sociological Review 63(1):137-45.

Putnam, Robert D. 2000. Bowling alone: The collapse and revival of American community. New York: Simon and Schuster.

Ronsvalle, John and Sylvia Ronsvalle. 1999. Basic trends in church giving: 1921-1995. In Financing American religion, edited by Mark Chaves and Sharon L. Miller, pp. 11-20. Walnut Creek, CA: AltaMira.

Roof, Wade Clark. 1993. A generation of seekers: The spiritual journeys of the baby boom generation. San Francisco: Harper.

Smith, Tom W. 1998. A review of church attendance measures. American Sociological Review 63(1):131-36.

Smith, Tom W. and Seokho Kim. 2005. The vanishing Protestant majority. Journal for the Scientific Study of Religion 44:211-23.

Spilka, Bernard, Ralph W. Hood, Jr., Bruce Hunsberger, and Richard Gorsuch. 2003. The psychology of religion, 3rd ed. New York: Guilford.

Steinberg, Richard and Mark Wilhelm. 2003. Tracking giving across generations. New Directions for Philanthropic Fundraising 42:71-82.

Sullivan, Dennis H. 1985. Simultaneous determination of church contributions and church attendance. Economic Inquiry 24(2):309-20.

Wilhelm, Mark O., Eleanor Brown, Patrick M. Rooney, and Richard Steinberg. 2001. The Center on Philanthropy Panel Study [machine-readable data file]/Director and Principle Investigator, Mark O. Wilhelm; Co-Principle Investigators, Eleanor Brown, Patrick M. Rooney, and Richard Steinberg; Sponsored by Atlantic Philanthropies. In the Panel Study of Income Dynamics Wave XXXII [machine-readable data file]/Director and Principle Investigator, Frank P. Stafford; Co-Principle Investigators, Robert F. Schoeni, Jacquelynne S. Eccles, Katherine McGonagle, and Wei_Jun Jean Yeung. Ann Arbor: Institute for Social Research, The University of Michigan.

Wilhelm, Mark. O. 2006a. The quality and comparability of survey data on charitable giving. Nonprofit and Voluntary Sector Quarterly (in press).

- 2006b. New data on charitable giving in the PSID. Economics Letters 92(1):26-31.

Zaleski, Peter A. and Charles E. Zech. 1994. Economic and attitudinal factors in Catholic and Protestant religious giving. Review of Religious Research 36(2):158-67.

Zech, Charles E. 2000. Generational differences in the determinants of religious giving. Review of Religious Research 41(4):545-59. 


\section{QUERIES}

Q1 Author: Reference Wilhelm et al. 2002 is not present in the reference list. Please check.

Q2 Author: Please check the suggested running head for correctness.

Q3 Author: Hoge et al. (1999) not cited in the text. Please check.

Q4 Author: Please update reference Wilhelm (2006a). 